\title{
Urgences
}

\section{Corps amerissant, jouissant avec la mer}

\section{Monique Dumais}

Numéro 14, août 1986

Corps et jouissances

URI : https://id.erudit.org/iderudit/025257ar

DOI : https://doi.org/10.7202/025257ar

Aller au sommaire du numéro

Éditeur(s)

Urgences

ISSN

0226-9554 (imprimé)

1927-3924 (numérique)

Découvrir la revue

Citer ce document

Dumais, M. (1986). Corps amerissant, jouissant avec la mer. Urgences, (14), 7-9.

https://doi.org/10.7202/025257ar

Ce document est protégé par la loi sur le droit d'auteur. L’utilisation des services d’Érudit (y compris la reproduction) est assujettie à sa politique d'utilisation que vous pouvez consulter en ligne.

https://apropos.erudit.org/fr/usagers/politique-dutilisation/
Cet article est diffusé et préservé par Érudit.

Érudit est un consortium interuniversitaire sans but lucratif composé de l’Université de Montréal, l’Université Laval et l’Université du Québec à Montréal. Il a pour mission la promotion et la valorisation de la recherche. https://www.erudit.org/fr/ 


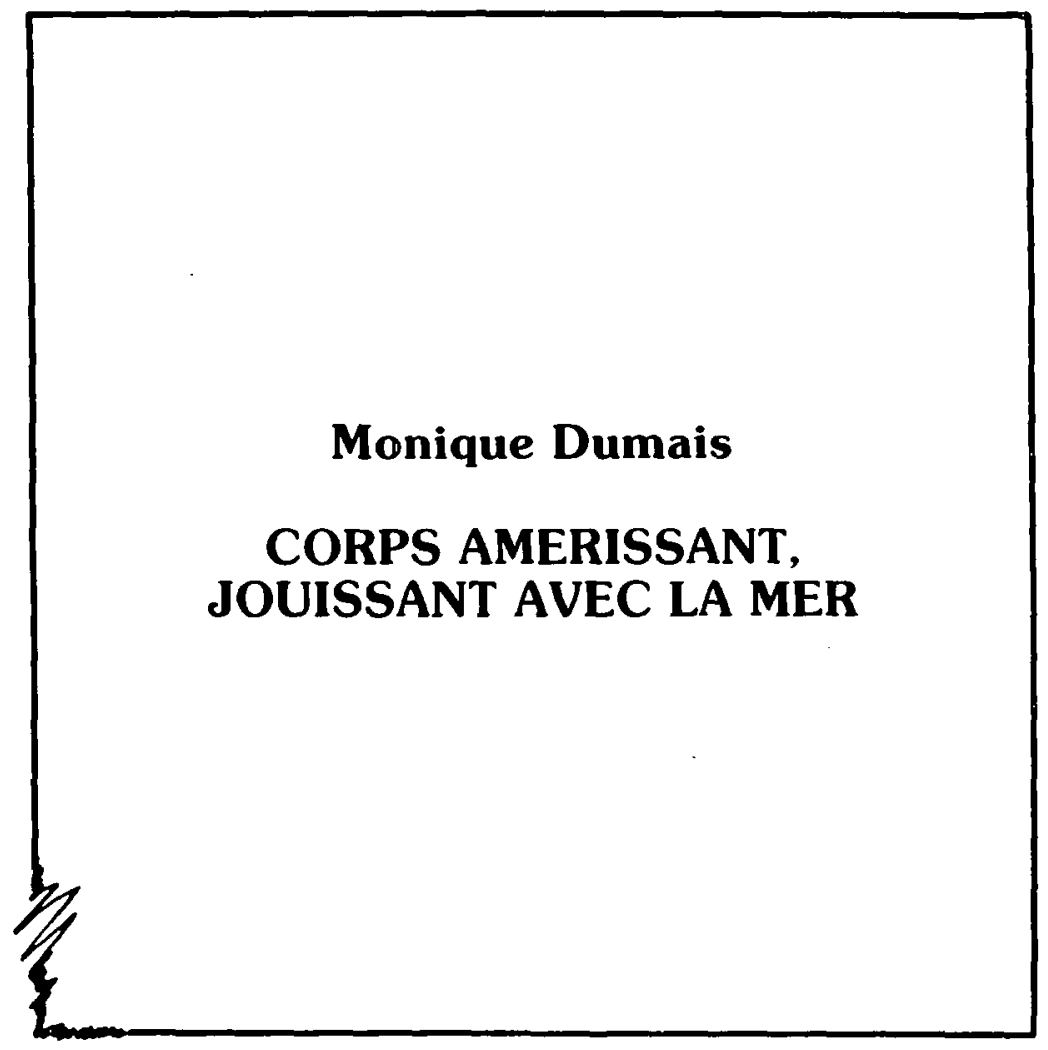


Marée montante,

Vagues qui s'enhardissent,

Qui viennent claquer contre les rochers, Jaillissements d'écume,

Mouvement ininterrompu,

Avance conquérante.

Je suis étendue sur le sable chaud.

Premières gouttelettes

D'eau salée sur mon corps,

Chatouillement sournois

De mes orteils,

Approches progressives,

Caresses humides

De mes jambes.

Prise de distance,

Retour en force

Recouvrement des cuisses

De l'abdomen.

Nouveau coup de mer

Qui encercle mes seins

Frémissement. Plaisir.

Séduction réussie. 
Corps et jouissance se conjugent pour moi avec la mer qui m'a vue grandir le long de ses rives. Tous les sens y participent.

Les yeux se baignent dans les nombreux miroitements du bleu et du vert, du gris et de l'argent, et du blanc laiteux soulevé dans les airs.

Les oreilles naviguent dans un ensemble de clapotis, de bruits en sourdine, de tintements sur les cailloux, de grondements tumultueux.

Les narines se dilatent vers les odeurs iodées, par la force des vents du large, ou par l'affleurement de la brise chaude.

Les papilles se délectent dans les saveurs étonnantes de varech salé, dans les tombées inopportunes d'eau brumeuse.

Tout le corps se laisse toucher, s'abandonne au flux et reflux de cet élément liquide si primordial et si fugitif.

Jouissance qui se liquëfie, qui s'évanouit et qui se ranime, avec les marées qui montent et se démontent. 